Subscriber access provided by Caltech Library

\title{
Article
}

\section{EPR spectroscopy of iron- and nickel-doped [ZnAl]-layered double hydroxides: modeling active sites in heterogeneous water oxidation catalysts}

\author{
Richard I. Sayler, Bryan M. Hunter, Wen Fu, Harry B. Gray, and R. David Britt
}

J. Am. Chem. Soc., Just Accepted Manuscript • DOI: 10.1021/jacs.9b10273 • Publication Date (Web): 31 Dec 2019

Downloaded from pubs.acs.org on January 1, 2020

\section{Just Accepted}

"Just Accepted" manuscripts have been peer-reviewed and accepted for publication. They are posted online prior to technical editing, formatting for publication and author proofing. The American Chemical Society provides "Just Accepted" as a service to the research community to expedite the dissemination of scientific material as soon as possible after acceptance. "Just Accepted" manuscripts appear in full in PDF format accompanied by an HTML abstract. "Just Accepted" manuscripts have been fully peer reviewed, but should not be considered the official version of record. They are citable by the Digital Object Identifier (DOI®). "Just Accepted" is an optional service offered to authors. Therefore, the "Just Accepted" Web site may not include all articles that will be published in the journal. After a manuscript is technically edited and formatted, it will be removed from the "Just Accepted" Web site and published as an ASAP article. Note that technical editing may introduce minor changes to the manuscript text and/or graphics which could affect content, and all legal disclaimers and ethical guidelines that apply to the journal pertain. ACS cannot be held responsible for errors or consequences arising from the use of information contained in these "Just Accepted" manuscripts. 


\title{
EPR spectroscopy of iron- and nickel-doped [ZnAl]-layered double
}

\section{hydroxides: modeling active sites in heterogeneous water oxidation catalysts}

\author{
Richard I. Sayler ${ }^{\dagger}$, Bryan M. Hunter ${ }^{\dagger}$, Wen Fu ${ }^{\dagger}$, Harry B. Gray ${ }^{\ddagger}$, and R. David Britt ${ }^{\star \dagger}$ \\ tDepartment of Chemistry, University of California at Davis, Davis, California 95616, United States \\ ¥Division of Chemistry and Chemical Engineering, California Institute of Technology, Pasadena, \\ California 91125, United States
}

\begin{abstract}
Iron-doped nickel layered double hydroxides (LDHs) are among the most active heterogeneous water oxidation catalysts. Due to inter-spin interactions, however, the high density of magnetic centers results in line-broadening in magnetic resonance spectra. As a result, gaining atomic-level insight into the catalytic mechanism via electron paramagnetic resonance (EPR) is not generally possible. To circumvent spinspin broadening, iron and nickel atoms were doped into non-magnetic [ZnAl]-LDH materials and the coordination environments of the isolated $\mathrm{Fe}(\mathrm{III})$ and $\mathrm{Ni}(\mathrm{II})$ sites were characterized. Multifrequency EPR spectroscopy identified two distinct $\mathrm{Fe}(\mathrm{III})$ sites $(S=$ 5/2) in [Fe:ZnAl]-LDH. Changes in zero field splitting (ZFS) were induced by dehydration of the material, revealing that one of the $\mathrm{Fe}(\mathrm{III})$ sites was solvent-exposed (i.e. at an edge, corner, or defect site). These solvent-exposed sites featured an axial ZFS of 0.21 $\mathrm{cm}^{-1}$ when hydrated. The ZFS increased dramatically upon dehydration (to $-1.5 \mathrm{~cm}^{-1}$ ), owing to lower symmetry and a decrease in the coordination number of iron. The ZFS of
\end{abstract}


the other ("inert") $\mathrm{Fe}$ (III) site maintained an axial ZFS of $0.19-0.20 \mathrm{~cm}^{-1}$ under both hydrated and dehydrated conditions. We observed a similar effect in [Ni:ZnAl]-LDH materials; notably, $\mathrm{Ni}(\mathrm{II})(S=1)$ atoms displayed a single, small ZFS $\left( \pm 0.30 \mathrm{~cm}^{-1}\right)$ in hydrated material, whereas two distinct Ni(II) ZFS values $\left( \pm 0.30\right.$ and $\left.\pm 1.1 \mathrm{~cm}^{-1}\right)$ were observed in the dehydrated samples. Although the magnetically-dilute materials were not active catalysts, the identification of model sites in which the coordination environments of iron and nickel were particularly labile (e.g. by simple vacuum drying) is an important step towards identifying sites in which the coordination number may drop spontaneously in water, a probable mechanism of water oxidation in functional materials.

\section{Introduction}

In oxygenic photosynthesis, plants use water as the electron source for storing energy in chemical bonds. In nature, these bonds typically reside in carbohydrates. Lacking the complex protein machinery to functionally mimic plants, we often design systems to store energy in the simplest diatomic covalent bond: dihydrogen $\left(\mathrm{H}_{2}\right)$. Regardless of its ultimate form, fuel production relies on water oxidation to generate protons and electrons. Major hurdles in the development of scalable systems for splitting water include the high overpotential needed for the 4-electron/4-proton redox reaction as well as the low rates of catalysis by earth-abundant materials. ${ }^{1} \mathrm{It}$ is notable that these limitations are present even in rare-element catalysts.

The layered double hydroxide (LDH) (Figure 1) structure, which is commonly found in nature (e.g. brucite), has been increasingly employed as a robust framework 
for water oxidation electrocatalysis. ${ }^{2,3}$ The [NiFe]-LDH electrocatalysts [in which some of the nickel(II) sites have been replaced by iron(III)] have been extensively studied in recent years, with iron incorporation playing a critical role in water oxidation activity. ${ }^{4}$ Even accidental intercalation of adventitious iron into first-row transition metal LDHs enhances catalytic performance. ${ }^{5}$

In efforts to further improve these heterogeneous catalysts, detailed knowledge of the metal coordination environments is a prerequisite for determining the mechanism by which they operate. A necessary step in the electro-oxidation of water is the liberation of molecular oxygen, generating a low-valent, coordinatively unsaturated metal site which can then weakly bind water or hydroxide. Complicating the issue, not all sites are equivalent in anisotropic nanoparticles or electrodeposited materials, as these structures have bulk, edge, corner, and interstitial sites, each with a different coordination environment. ${ }^{6-8}$ In the case of nickel-containing LDH materials, there is little consensus on the mechanism of intercalated iron. While some investigators support the view that surface iron species are the active sites, ${ }^{9}$ others propose that the nickel sites are responsible for catalysis. ${ }^{10}$ 


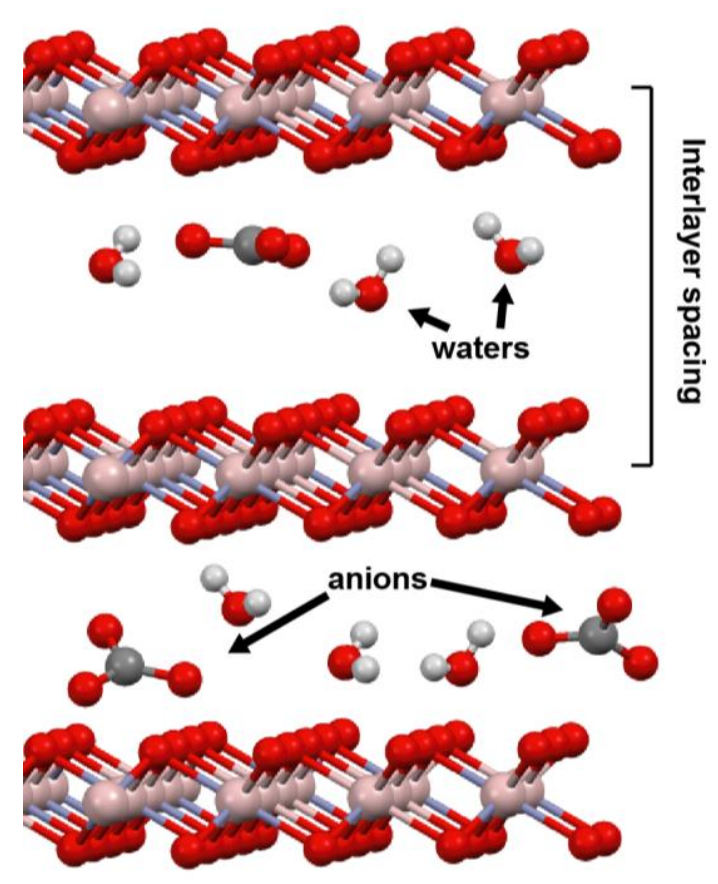

Figure 1. Depiction of an LDH structure with carbonate anions in the interlayer space. Hydroxide hydrogens in the material are omitted for clarity. Oxygen atoms (red), metal atoms (pink), hydrogen atoms (white), and carbon atoms (black).

Recently, Boettcher and coworkers have proposed that the increased activity of Fe-doped $\mathrm{NiO}_{x}$ materials is due to edge Fe sites as opposed to bulk Fe sites.${ }^{11}$ In other first-row transition metal oxides/hydroxides (e.g. CoPi and [NiFe]-LDHs), edges and corners have been identified as most likely to show enhanced catalysis. ${ }^{6,8,11,12}$ Additionally, computational studies have suggested that edge iron sites are more active than similar nickel sites in a mixed-metal nickel-iron oxyhydroxide lattice. ${ }^{7}$

In theory, electron paramagnetic resonance (EPR) spectroscopy should be a sensitive indicator of the coordination environment of catalytic metal sites. In practice, however, the X-band continuous wave (CW) EPR spectra of (1) [NiFe]-LDH, ${ }^{13}(2)$ electrodeposited $\mathrm{Ni}(\mathrm{II})$ in borate ${ }^{14}(\mathrm{NiB}$, which is structurally similar to $\mathrm{LDH}),{ }^{15}$ and 
coprecipitated FeOOH (goethite) ${ }^{16}$ display no signals from isolated metal centers (Figure 2, 1-3): Instead, all three materials feature very broad EPR lineshapes (Figure $2,1-3)$ that result from strong inter-spin electronic couplings between the high density paramagnetic metal centers. Additionally, fast relaxation times make these magnetically dense LDHs unsuitable for pulsed EPR studies, unlike, for example, the Mn-Ca OEC of photosystem II. ${ }^{17-19}$ For these reasons, the very limited spectral information we can gather prohibits detailed analysis of individual sites. 


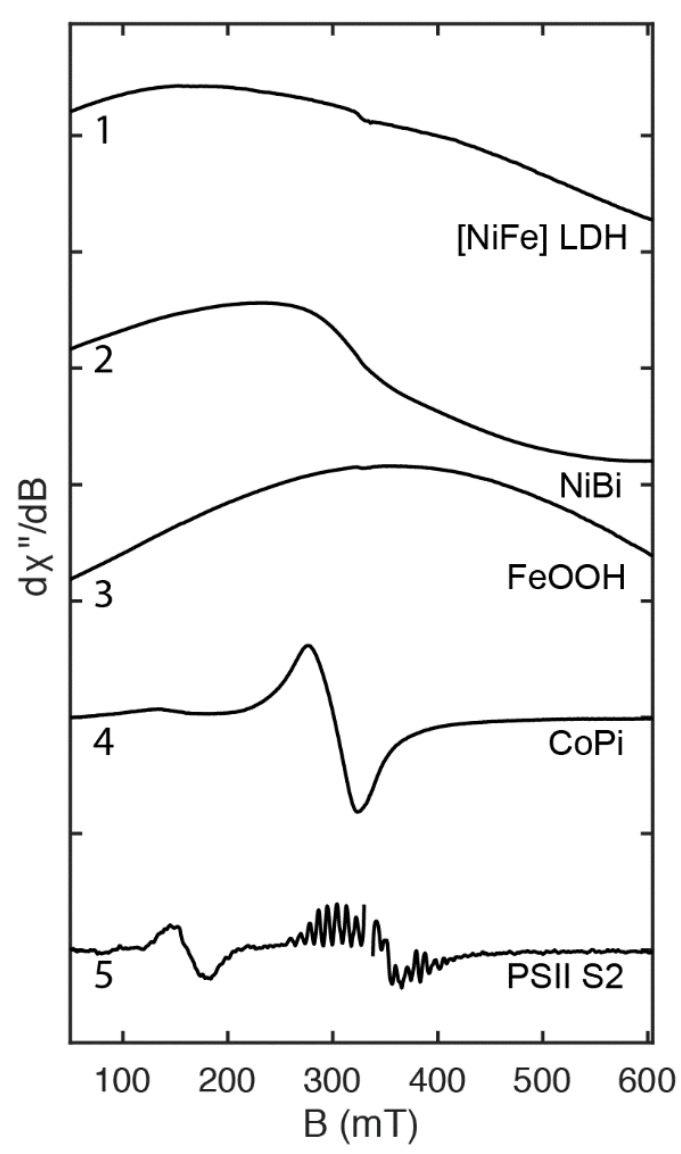

Figure 2. EPR spectra of materials relevant to water oxidation catalysis: (1) $5 \mathrm{mg}$ of [NiFe]-LDH nanopowder synthesized by pulsed laser ablation in liquids (PLAL); ${ }^{17-19}$ (2) $5 \mathrm{mg}$ of $\mathrm{NiB}$ i powder synthesized by electrodeposition; ${ }^{14}$ (3) $5 \mathrm{mg}$ of $\mathrm{FeOOH}$ powder synthesized by coprecipitation; ${ }^{16}$ (4) $5 \mathrm{mg}$ of $\mathrm{CoP}$ synthesized by electrodeposition and subsequent electrochemical oxidation; ${ }^{20}(5) \mathrm{X}$-band CW EPR of the S2 state in spinach BBY membranes. ${ }^{21}$ Acquisition parameters: (1-3) microwave frequency $=9.4 \mathrm{GHz}$; temperature $=20 \mathrm{~K} ;$ microwave power $=2.0 \mathrm{~mW}$; modulation amplitude $=0.5 \mathrm{mT} ;$ (4) microwave frequency $=9.4 \mathrm{GHz}$; temperature $=40 \mathrm{~K}$; microwave power $=2.0 \mathrm{~mW}$; modulation amplitude $=0.5 \mathrm{mT}$; (5) microwave frequency $=9.4 \mathrm{GHz}$; temperature $=7 \mathrm{~K}$; microwave power $=200 \mu \mathrm{W}$; modulation amplitude $=0.5 \mathrm{mT}$. 
Fortunately EPR spectroscopy has been successfully employed to characterize the coordination environments and electronic structures of paramagnetic centers in a some extended solids with catalytic properties, including anatase $\left(\mathrm{TiO}_{2}\right),{ }^{22}$ cobalt oxide $(\mathrm{CoO} \times),{ }^{23}$ zeolites,${ }^{24-26}$ and metal-organic frameworks. ${ }^{27} \mathrm{~A}$ recent example of a wellcharacterized metal oxide system is the $\mathrm{CoP}_{\mathrm{i}}$ catalyst, in which the bulk of the material is low-spin, diamagnetic Co(III). This EPR-silent background allows characterization of relatively well isolated $S=1 / 2 \mathrm{Co}(\mathrm{IV})$ sites (Figure 2, 4). ${ }^{23}$ Even in this relatively wellbehaved system, pulsed EPR results have not been reported due to relatively fast spinspin relaxation. Compared to the well-studied $S=1 / 2 \mathrm{~S}_{2}$-state of the $\mathrm{Mn}_{4} \mathrm{CaO}_{5}$ cluster in photosystem II (Figure 2, 5), ${ }^{17-19}$ relatively little information about the electronic $g$ values and hyperfine interactions can be gleaned in the absence of data from measurements employing a combination of multifrequency CW spectra supplemented by higher resolution pulsed EPR techniques. ${ }^{28,29}$

In order to mimic the desirable magnetic properties of $\mathrm{CoP}_{\mathrm{i}}$, we doped iron and nickel atoms into a non-magnetic [ZnAl]-LDH material, with the ultimate goal of using EPR spectroscopy to extract the electronic and geometric information of isolated $\mathrm{Fe}$ (III) and $\mathrm{Ni}(\mathrm{II})$ paramagnetic centers. With the resulting data, we hoped to make comparisons among disparate heterogeneous water oxidation catalysts ${ }^{13,30}$ and draw connections to homogeneous models where mechanisms are better understood. ${ }^{31-33}$ Here we report the magnetic parameters of different types of $\mathrm{Fe}(\mathrm{III})$ and $\mathrm{Ni}(\mathrm{II})$ sites in LDH structures. The primary (aquo/hydroxide) coordination spheres of differentiable $\mathrm{Ni}(\mathrm{II})$ and $\mathrm{Fe}(\mathrm{III})$ sites were probed using multifrequency CW EPR 
spectroscopy following hydration and dehydration cycles. At X-band $(9.4 \mathrm{GHz})$ and Qband (34 GHz) frequencies, no pulsed EPR signals were observed in either the Fe(III) or $\mathrm{Ni}(\mathrm{II})$ doped materials. Interestingly, electron spin echo signals were observed for the iron-doped material at $\mathrm{D}$-band $(130 \mathrm{GHz})$. This unexpected finding has opened the way for in-depth investigations of complex LDH high-spin systems by high frequency/high field pulsed EPR. ${ }^{18,34}$

\section{Materials and Methods}

Materials synthesis

Dilute $L D H s$ : A solution of $6 \mathrm{mM} \mathrm{Zn}\left(\mathrm{NO}_{3}\right)_{2}$ and $2 \mathrm{mM}$ of a variable mixture of $\mathrm{Al}\left(\mathrm{NO}_{3}\right)_{3}$ and $\mathrm{Fe}\left(\mathrm{NO}_{3}\right)_{3}$ was slowly added $(1 \mathrm{~mL} / \mathrm{min})$ to a carbonate buffered solution (1 $\mathrm{M}, \mathrm{pH}$ 10). A cream-colored coprecipitate formed (at higher Fe concentrations the solid was more orange) and the solution was stirred at $50^{\circ} \mathrm{C}$ for one hour while adjusting the $\mathrm{pH}$ with $1 \mathrm{M} \mathrm{KOH}$ to maintain $\mathrm{pH} 10$. The coprecipitate was filtered and the clay-like solid was dried at $100{ }^{\circ} \mathrm{C}$ for one hour. A solution of $2 \mathrm{mM} \mathrm{Al}\left(\mathrm{NO}_{3}\right)_{3}$ and $2 \mathrm{mM}$ of a variable mixture of $\mathrm{Zn}\left(\mathrm{NO}_{3}\right)_{2}$ and $\mathrm{Ni}\left(\mathrm{NO}_{3}\right)_{2}$ was slowly added $(1 \mathrm{~mL} / \mathrm{min})$ to a carbonate buffered solution (1 M, pH 10). A cream-colored coprecipitate formed (at higher $\mathrm{Ni}$ concentrations the solid was more seafoam green) and the solution was stirred at $50^{\circ} \mathrm{C}$ for one hour while adjusting the $\mathrm{pH}$ with $1 \mathrm{M} \mathrm{KOH}$ to maintain $\mathrm{pH} 10$. The coprecipitate was filtered and the clay-like solid was dried at $100^{\circ} \mathrm{C}$ for one hour.

Nickel borate $\left(\mathrm{NiB}_{i}\right)$ and cobalt phosphate $\left(\mathrm{CoP}_{i}\right)$ : thin films were synthesized electrochemically according to literature procedures. ${ }^{14,20}$ The films were subsequently scraped off the electrode, packed into an EPR tube, and frozen at $77 \mathrm{~K}$. 
[NiFe]-LDH: nanoparticles were synthesized by a pulsed laser ablation in liquids (PLAL) method described previously. ${ }^{13}$

Materials characterization

Syntheses were successful with metal solutions containing $M(I I)$ and $M(I I I)$ ions in a 3:1 ratio. ${ }^{2}$ The material phases were confirmed by powder X-ray diffraction (PXRD). Good agreement with literature PXRD patterns for [ZnAl]-LDH indicated the formation of the LDH structure. Slight variations between the [ZnAl]-LDH and [Fe:ZnAl]-LDH patterns were apparent, likely due to changes in the unit cell upon the addition of $\mathrm{Fe}$ (III) (Figure S1). PXRD data were collected at room temperature using a Bruker D8 ADVANCE Eco at $40 \mathrm{kV}$ and $25 \mathrm{~mA}$. The data were collected in the $5^{\circ}-70^{\circ} 2 \theta$ range with a step size of $0.0143^{\circ}$ and $0.5 \mathrm{~s} /$ step. Intensities were normalized (Figures S1 and S2).

\section{Electron paramagnetic resonance}

X-band CW EPR spectroscopy: EPR samples were prepared either as a dry powder or suspended in $18 \mathrm{M} \Omega$ water. X-band continuous-wave (CW) EPR spectra were recorded on a Bruker ELEXSYS E500 spectrometer equipped with a cylindrical TE 011 -mode resonator (SHQE-W), an ESR 900-liquid helium cryostat, and an ITC-5 temperature controller (Oxford Instruments). Spectra were acquired under slowpassage non-saturating conditions. Background EPR signals from the host [ZnAl]-LDH were differentiated using [ZnAl]-LDH control materials. Oxygen atom radicals and vacancy signals were predictably distinct from observed spectra.

For systems with $S>1 / 2$, including high-spin $\mathrm{Fe}(\mathrm{III})$ or $\mathrm{Ni}(\mathrm{II})$, the spin Hamiltonian was parameterized as in Eqs. 1-3: 


$$
\begin{aligned}
& H_{e f f}=H_{e z}+H_{z f s} \\
& H_{e z}=g \beta m_{S} B \\
& H_{z f S}=D\left[S_{z}^{2}-\frac{1}{3} S^{2}+E / D\left(S_{x}^{2}-S_{y}^{2}\right)\right]
\end{aligned}
$$

where $H_{\mathrm{ez}}$ is the electronic Zeeman energy, $H_{z f s}$ is the zero-field splitting (ZFS) energy, $D$ is the axial contribution to the ZFS, and $E$ is the rhombic contribution to the ZFS. These parameters were used to describe the coordination sphere of the metal center, as splitting only arise when the electronic structure of the metal center is perturbed by ligands. Spin Hamiltonian parameters were determined by numerically simulating multifrequency EPR spectra with the Easy Spin toolbox for MATLAB 5.1.5. ${ }^{35}$

High frequency EPR spectroscopy: All pulsed EPR studies were conducted on a $130 \mathrm{GHz}$ EPR spectrometer ${ }^{36}$ equipped with a TE 011 mode cylindrical resonant cavity designed and manufactured by HF EPR Instruments, Inc. (V. Krymov, New York). The spectrometer features an Oxford-CF935 liquid helium cryostat and an ITC-503 temperature controller. The external magnetic field was generated with an $8 \mathrm{~T}$ cryogenfree magnet (Cryogenic Limited, UK). Field-swept echo-detected EPR spectra were acquired using a Hahn echo detection sequence: $\pi / 2-\tau-\pi-\tau-$ echo.

\section{Electrochemical characterization}

Linear sweep voltammetry (LSV) and chronoamperometry (CA) were conducted on a Princeton Applied Research (Oak Ridge, TN, USA) Model 263 A potentiostat in a three-electrode system. The reference electrode was an $\mathrm{Ag} / \mathrm{AgCl}(3 \mathrm{M} \mathrm{NaCl})$ electrode (BASi, West Lafayette, IN, USA). The working electrode was prepared by drop-casting 1 
$\mathrm{cm}^{2}$ of a $1 \mathrm{~cm} \times 2 \mathrm{~cm}$ fluorine doped tin oxide plate (FTO, Sigma Aldrich Inc., Milwaukee, WI, USA) with $12 \mu \mathrm{g}$ [Fe:ZnAl]-LDH or [Ni:ZnAl]-LDH from a sonicated suspension in $18 \mathrm{M} \Omega \mathrm{H}_{2} \mathrm{O}$. The counter electrode was nickel foam. The electrolyte was $15 \mathrm{~mL}$ of $0.5 \mathrm{M}$ sodium phosphate buffer ( $\mathrm{pH} 7 \mathrm{or} \mathrm{pH}$ 9). The LSV was taken from the open circuit potential swept to $1.5 \mathrm{~V}(\mathrm{vs} \mathrm{Ag} / \mathrm{AgCl})$ and $\mathrm{CA}$ was recorded at an overpotential of $\sim 800 \mathrm{mV}$. All LSV and CA experiments were conducted with stirring.

\section{Results}

The X-band CW EPR signals of $\mathrm{NiBi}, \mathrm{FeOOH}$, and [NiFe]-LDH were found to be broad and featureless at low temperature (Figure 2, 1-3), suggesting that each metal center experiences exchange interactions between nearest neighbor sites and dipolar coupling interactions with more distant ions. These interactions give rise to spectral broadening that obscured information about individual paramagnetic centers. Magnetically dilute iron- and nickel-containing [ZnAl]-LDH particles were synthesized to overcome this limitation (vide supra).

The X-band spectra of [Fe:ZnAl]-LDH (with $10-25 \%$ iron) at $20 \mathrm{~K}$ featured broad signals similar to those of the low-temperature [NiFe]-LDH material (Figure $\mathbf{3 A}, \mathbf{1}$ and 2). At low iron concentrations (1-5\% iron), however, the following signals were discernable: (1) a sharp signal at $180 \mathrm{mT}$; (2) a positive shoulder from 80 to $110 \mathrm{mT}$; and (3) a negative feature centered at $335 \mathrm{mT}$ (Figure 3A, 3 and 4). These spectral features sharpened and decreased in intensity as the iron concentration decreased. To probe the integer spin states of nickel, parallel-mode X-band CW EPR spectra were recorded for [Ni:ZnAl]-LDHs with varying nickel concentration. A negative feature 


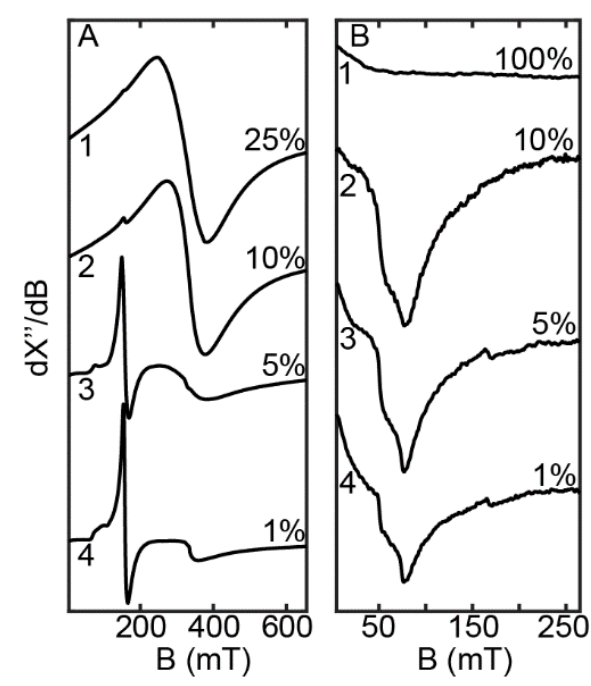

Figure 3. A: Perpendicular-mode EPR spectra of [Fe:ZnAl]-LDH with indicated iron concentrations [Zno.75Alo.25-xFex $\left.(\mathrm{OH})_{2}\right][\mathrm{A}]$ 0.25. B: Parallel-mode EPR spectra of [Ni:ZnAl]$\mathrm{LDH}$ with indicated nickel concentrations $\left[\mathrm{Zn}_{0.75-x} \mathrm{Al}_{0.25} \mathrm{Nix}_{x}(\mathrm{OH})_{2}\right][\mathrm{A}]_{0.25}$. Spectra were acquired at $9.4 \mathrm{GHz}, 20 \mathrm{~K}$, and $502 \mu \mathrm{W}$ power. [A] is an arbitrary anion, predominantly carbonate at high $\mathrm{pH}$.

\begin{abstract}
at $80 \mathrm{mT}$ was observed for [Ni:ZnAl]-LDH (with 1-20\% nickel); this feature, which was not present in pure $\mathrm{NiOOH}$ (Figure 3B), sharpened and decreased in intensity as the $\mathrm{Ni}($ II) concentration decreased.
\end{abstract}




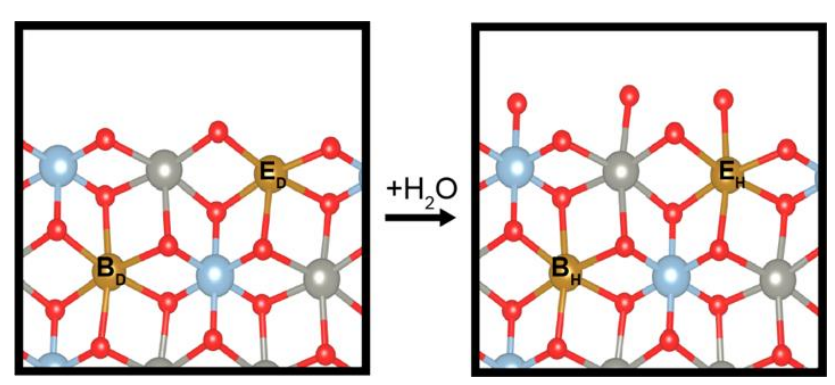

Figure 4. Depiction of edge $(\mathrm{E})$ and interstitial $(\mathrm{B})$ sites under hydrated $(\mathrm{H})$ and dehydrated (D) conditions. Atoms are labeled as follows: orange (iron or nickel), gray (zinc), light blue (aluminum), and red (oxygen).

\footnotetext{
Based on the structure of LDH materials, we assigned types of Fe and Ni sites in the bulk (B) and in edge, corner, or defect sites (E). These sites were then considered in hydrated (H) (Figure 4A) or dehydrated (D) (Figure 4B) states. Although dehydrated [Fe(1\%):ZnAl]-LDH yielded the CW EPR spectrum shown above (Figure 5, as synthesized), several noticeable changes were observed after suspending the sample in water overnight. Upon hydration, the signals at 335 and $110 \mathrm{mT}$ decreased in intensity, while the feature at $40 \mathrm{mT}$ was stronger (Figure 5, hydrated). No changes were observed in the intensities at 80 and $180 \mathrm{mT}$. These changes were reversible over several hydration-dehydration cycles (Figure 5, hydrated, dehydrated). Spectral features also were highly dependent on water being the solvent; no changes were observed when the dehydrated sample was subsequently treated with acetonitrile.
} 


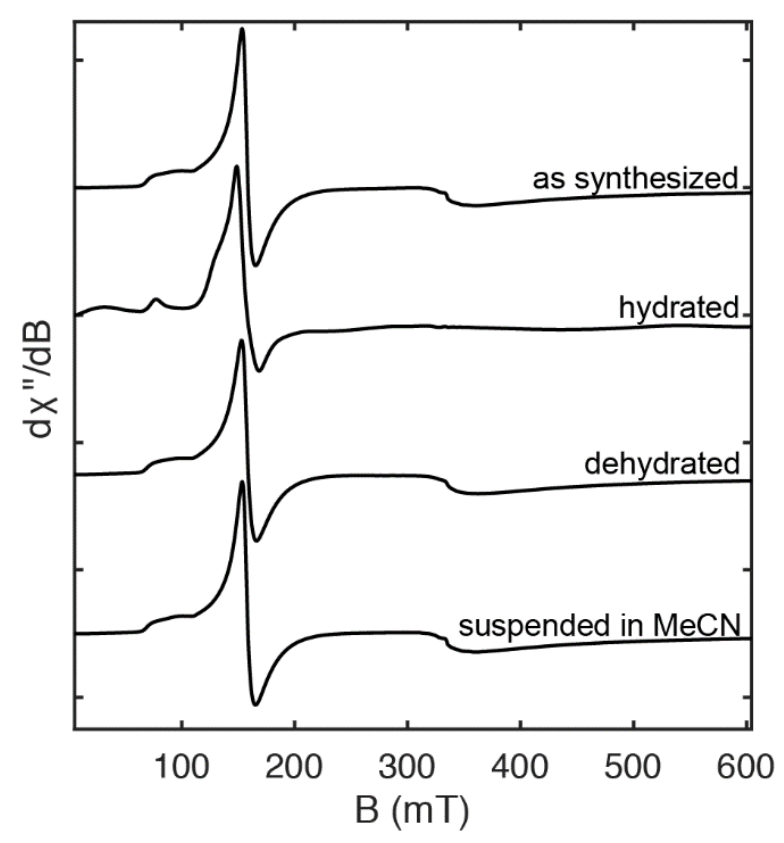

Figure 5. EPR spectra of [Fe:ZnAl]-LDH (with 1\% iron) under different solvation conditions, as indicated. Spectra were acquired at $9.4 \mathrm{GHz}$ and $502 \mu \mathrm{W}$ microwave power.

The spectra for [Fe:ZnAl]-LDH were best simulated with two types of $S=5 / 2$ sites. In the absence of pulsed EPR experiments, determination of accurate magnetic parameters is very challenging. Fortuitously, the [Fe:ZnAl]-LDH (with $1 \%$ iron) gave an observable electron spin echo at $130 \mathrm{GHz}$ and $10 \mathrm{~K}$ (Figure 6C and 6D), a rare example of echo-detected high-spin Fe(III) centers. Subsequent high-frequency pulsed echo experiments allowed us to simulate spectra at multiple frequencies, providing an accurate determination of $D$ and $E$ parameters. 

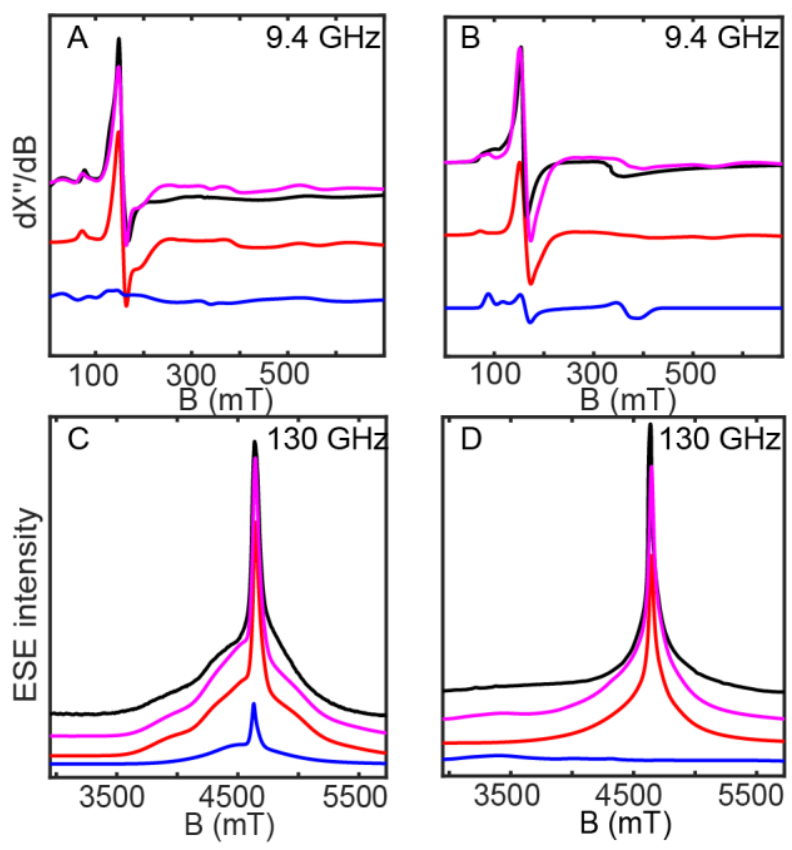

Figure 6. CW and pulsed spin echo spectra of hydrated [Fe:ZnAl]-LDH (left) and dehydrated [Fe:ZnAl]-LDH (right). Panels $\mathbf{A}$ and $\mathbf{B}$ at $9.4 \mathrm{GHz}(30 \mathrm{~K})$; panels $\mathbf{C}$ and $\mathbf{D}$ at $130 \mathrm{GHz}(7 \mathrm{~K})$. Simulation parameters: class $\mathrm{BH}_{\mathrm{H}}$ (red, panels A and C) $\mathrm{S}=5 / 2, g=$ 2.003, $\mathrm{D}=0.20 \mathrm{~cm}^{-1}, E=0.044 \mathrm{~cm}^{-1} ;$ class $\mathrm{BD}$ (red, panels $B$ and $\mathrm{D}$ ) $\mathrm{S}=5 / 2, g=2.003$, $\mathrm{D}=0.19 \mathrm{~cm}^{-1}, \mathrm{E}=0.050 \mathrm{~cm}^{-1}$; class $\mathrm{E}_{H}$ (blue, panels A and C) $\mathrm{S}=5 / 2, g=2.003, \mathrm{D}=$ $0.21 \mathrm{~cm}^{-1}, E=0.020 \mathrm{~cm}^{-1}$; class $E_{D}$ (blue, panels A and C) $\mathrm{S}=5 / 2, g=2.003, \mathrm{D}=-1.5$ $\mathrm{cm}^{-1}, \mathrm{E}=0.32 \mathrm{~cm}^{-1}$. The sum of the components is in magenta.

The multifrequency spectra were fitted, yielding ZFS magnetic parameters of the various types of iron sites. The self-consistent $\mathrm{ZF}$ splittings for $\mathrm{BH}_{\mathrm{H}}(\mathrm{Fe})$ and $\mathrm{BD}(\mathrm{Fe})$ were simulated with $g=2.003$ (both), and $D=0.20 \mathrm{~cm}^{-1}$ and $0.19 \mathrm{~cm}^{-1}$ and $E=0.044 \mathrm{~cm}^{-1}$ and $0.050 \mathrm{~cm}^{-1}$, respectively, at 130 and $9.4 \mathrm{GHz}$ (Figure 6). The ZF splittings of $\mathrm{E}_{\mathrm{H}}(\mathrm{Fe})$ and $\mathrm{E}_{\mathrm{D}}(\mathrm{Fe})$ were simulated with $D=0.21$ and $-1.5 \mathrm{~cm}^{-1}, E=0.020$ and $0.32 \mathrm{~cm}^{-1}$, respectively, at 130 and $9.4 \mathrm{GHz}$. Echo intensity for $\mathrm{E}_{\mathrm{D}}(\mathrm{Fe})$ was observed down to 3000 
mT at $130 \mathrm{GHz}$, (Figure 6D); this was not the case for the hydrated material $\left[\mathrm{EH}_{\mathrm{H}}(\mathrm{Fe})\right]$ where the features were considerably narrower (Figure 6C). The assignments of multiple species also were tracked by observing the changes in spectral intensity as a function of temperature (see SI).

Spectra of nickel-containing LDHs exhibited similar structural changes upon hydration and dehydration. The X-band parallel-mode derivative spectrum of the initially dehydrated [Ni:ZnAl]-LDH (with 1\% nickel) featured a negative region centered at 80 $\mathrm{mT}$ and a minor positive signal at $160 \mathrm{mT}$ (Figure 7B). Upon hydration, the signal at $160 \mathrm{mT}$ was no longer observed, and the signal at $80 \mathrm{mT}$ was unchanged (Figure 7A). Further heating under vacuum $\left(150^{\circ} \mathrm{C}\right)$ resulted in increased intensity of the $160 \mathrm{mT}$ component.

The X-band parallel mode spectra of hydrated [Ni:ZnAl]-LDH were well-simulated by one type of $S=1$ site. Specifically, $\mathrm{BH}_{H}(\mathrm{Ni})=\mathrm{E}_{\mathrm{H}}(\mathrm{Ni}): g=\left[\begin{array}{lll}2.3 & 2.22 .2\end{array}\right], D= \pm 0.32 \mathrm{~cm}^{-1}$, and $E=0.050 \mathrm{~cm}^{-1}$ (Figure 7A). Simulation of dehydrated [Ni:ZnAl]-LDH required two different types of $S=1$ sites, with the following magnetic parameters: $\mathrm{BD}(\mathrm{Ni}): g=[2.3$

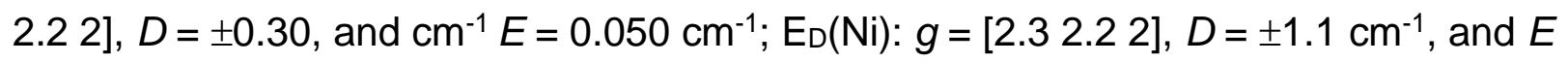
$=0.030 \mathrm{~cm}^{-1}$ (Figure 7B). The relatively small ZFS associated with $\mathrm{Ni}(\mathrm{II})$ sites made it possible to observe the "EPR-silent" $(S=1) \mathrm{Ni}(I I)$ via parallel-mode EPR. ${ }^{37}$ 

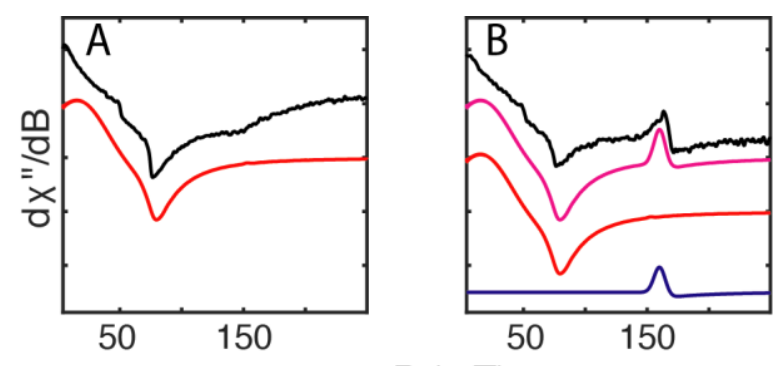

$\mathrm{B}(\mathrm{mT})$

Figure 7. Parallel-mode CW EPR spectra of $\mathbf{A}$ : hydrated [Ni:ZnAl]-LDH (with $1 \%$ nickel) and B: dehydrated [Ni:ZnAl]-LDH (with 1\% nickel). Spectra acquired at $9.4 \mathrm{GHz}, 5 \mathrm{~K}$ and $3.2 \mathrm{~mW}$ power. Simulations parameters: $\mathrm{B}_{\mathrm{D}}, \mathrm{B}_{\mathrm{H}}$, and $\mathrm{E}_{\mathrm{H}}$ (red, panels $\mathbf{A}$ and $\left.\mathbf{B}\right): S=$

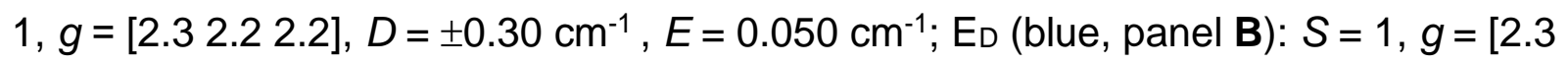
$2.22], D= \pm 1.1 \mathrm{~cm}^{-1}, E=0.030 \mathrm{~cm}^{-1}$. The sum of the components is in magenta.

$\mathrm{Ni}(\mathrm{III}), \mathrm{Fe}(\mathrm{IV}), \mathrm{Fe}(\mathrm{V})$ and $\mathrm{Fe}(\mathrm{VI})$ have all been implicated in the water oxidation mechanisms in the related NiFE LDH. ${ }^{9}$ The ability to monitor the oxidation state of the isolated Fe and Ni sites of [Fe:ZnAl]- LDH and [Ni:ZnAl]- LDH via EPR is of great interest in isolating mechanistically relevant higher oxidation state sites in these materials. Attempts to oxidize both [Fe:ZnAl]- LDH and [Ni:ZnAl]- LDH were made with a variety of chemical oxidants, including in both aqueous and non-aqueous solvents, though no new species could be attributed to oxidized Fe or Ni species. The complex chemical environment of these materials include water, hydroxide and anions such as carbonate and nitrate, which are known to react with high oxidation state $\mathrm{Fe}$ and/or $\mathrm{Ni}$ centers in these materials which could cause the rapid decay of high oxidation state intermediates.

The electrochemical properties of [Fe:ZnAl]-LDH and [Ni:ZnAl]-LDH were tested at $\mathrm{pH} 7$ and $\mathrm{pH} 9$ in potassium phosphate buffer. Linear sweep voltammetry and 
constant-potential chronoamperometry were conducted on a thin film of material made by drop casting $50 \mu \mathrm{L}$ of a $5 \mathrm{mg} / \mathrm{mL}$ suspension of materials onto a glassy carbon working electrode. These materials were found to anodically shift the onset potential of water oxidation relative to the bare electrode, likely due to the insulating quality of the dilute materials (Figure S8-S11). The chronoamperometric current also decreased relative to the bare electrode at doping levels of $<5 \% \mathrm{Fe}$ or Ni (Figure S8-S11). It is concluded that, while these materials are excellent structural models for active OER catalysts, they are not in themselves active.

\section{Discussion}

The broad, featureless EPR signals characteristic of $\mathrm{NiB}, \mathrm{FeOOH}$, and [NiFe]LDH at low temperatures are indicative of highly-coupled metal oxide particles each with a high density of paramagnetic sites. This spectral broadening limits the information obtainable by EPR spectroscopy, in particular the coordination environments of individual paramagnets.

Magnetically dilute model materials are able to overcome these limitations, and the features observed in 1-5\% [Fe:ZnAl]-LDH are signatures of isolated, high-spin $\mathrm{Fe}(\mathrm{III}) .{ }^{38}$ In addition, parallel-mode CW EPR can probe integer spin states [as in $\mathrm{Ni}(\mathrm{II})$ ], owing to mixing of microstates that causes relaxation of EPR selection rules. ${ }^{39} \mathrm{As}$ a result, both [Fe:ZnAl]-LDH and [Ni:ZnAl]-LDH exhibited spectral features indicative of isolated paramagnetic centers.

By coupling low frequency CW EPR with high-frequency echo-detected EPR, two types of sites were identified in 1\% [Fe:ZnAl]-LDH. The two bulk-site types, present 
under different hydration conditions, $\mathrm{B}(\mathrm{Fe})$, were well-simulated using virtually identical ZF splitting parameters (Table 1).

\begin{tabular}{|c|c|c|}
\hline & Bulk Class (B) & Edge Class (E) \\
\hline \multirow{2}{*}{ Dehydrated (D) } & $\begin{array}{r}\text { Fe } \quad D: 0.19 \mathrm{~cm}^{-1 \mathrm{a}, \mathrm{b}} \\
E: 0.050 \mathrm{~cm}^{-1 \mathrm{a}, \mathrm{b}}\end{array}$ & Fe $\begin{aligned} & D:-1.5 \mathrm{~cm}^{-1} \mathrm{a}, \mathrm{b}, \mathrm{d} \\
& E: 0.32 \mathrm{~cm}^{-1} \mathrm{a}, \mathrm{b}\end{aligned}$ \\
\hline & $\begin{array}{ll}\mathrm{Ni} & D: \pm 0.30 \mathrm{~cm}^{-1 \mathrm{c}} \\
& E: 0.050 \mathrm{~cm}^{-1 \mathrm{c}}\end{array}$ & $\begin{array}{ll}\text { Ni } & D: \pm 1.1 \mathrm{~cm}^{-1 \mathrm{c}} \\
& E: 0.030 \mathrm{~cm}^{-1} \mathrm{c}\end{array}$ \\
\hline \multirow[b]{2}{*}{ Hydrated (H) } & Fe $\begin{aligned} D: 0.20 \mathrm{~cm}^{-1} \mathrm{a}, \mathrm{b}, \mathrm{d} \\
E: 0.044 \mathrm{~cm}^{-1 \mathrm{a}, \mathrm{b}}\end{aligned}$ & Fe $\begin{aligned} D: 0.21 \mathrm{~cm}^{-1} \mathrm{a}, \mathrm{b}, \mathrm{d} \\
E: 0.020 \mathrm{~cm}^{-1 \mathrm{a}, \mathrm{b}}\end{aligned}$ \\
\hline & $\begin{array}{ll}\mathrm{Ni} & D: \pm 0.30 \mathrm{~cm}^{-1 \mathrm{c}} \\
& E: 0.050 \mathrm{~cm}^{-1 \mathrm{c}}\end{array}$ & $\begin{array}{l}\text { Ni } D: \pm 0.30 \mathrm{~cm}^{-1 \mathrm{c}} \\
E: 0.050 \mathrm{~cm}^{-1 \mathrm{c}}\end{array}$ \\
\hline
\end{tabular}

Table 1. ZF splitting parameters for isolated $\mathrm{Fe}(\mathrm{III})$ and $\mathrm{Ni}(\mathrm{II})$ sites in a magnetically dilute LDH material. a Determined from CW X-band simulation; ${ }^{b}$ Determined from pulsed D-band simulation; ' Determined from parallel-mode CW X-band simulation; ${ }^{d}$ Determined from CW X-band temperature dependence (Supporting Information section II).

Because only slight changes in ZF splitting were observed under both hydrated and dehydrated conditions, the iron sites likely are "locked" within the lattice. These sites, which contain triply bridging hydroxide ligands, will not be labile (Figure 4).

The assigned edge sites, $E(F e)$, required very different $Z F$ splitting parameters for simulations of hydrated vs. dehydrated materials (Table 1). The dramatic increase in ZF splittings indicates that the coordination environments of these metal centers are undergoing substantial changes. These edge, corner, and defect sites must be coordinated by labile waters or hydroxides, and ligand losses likely will occur upon 
heating. ${ }^{40,41,39}$ Five-coordinate (square pyramidal and trigonal bipyramidal) high-spin Fe(III) systems have ZF splittings similar to those of dehydrated sites (Table 2). When hydrated, both types of Fe sites (edge and interstitial) are coordinated by a full octahedral ligand set, with either $\mu_{3}$-oxo bonds or terminal waters and hydroxides. The highly symmetric coordination environment, along with Fe-O bond covalency, gave rise to small ZF splittings ${ }^{42}$ in $\mathrm{BH}_{\mathrm{H}}(\mathrm{Fe}), \mathrm{BD}_{\mathrm{D}}(\mathrm{Fe})$, and $\mathrm{E}_{\mathrm{H}}(\mathrm{Fe})$. The extremely broad spectrum seen in the high-frequency echo-detected spectrum was expected, as the microwave excitation energy is of similar magnitude to the axial ZFS parameter $\left(D=-1.5 \mathrm{~cm}^{-1}, f_{\mathrm{mw}}\right.$ $\left.=4.3 \mathrm{~cm}^{-1}\right)$.

Similar site-specific assignments have been made in Fe-doped zeolites. ${ }^{43}$ In zeolite systems, a characteristic $g=2$ signal is observed and assigned to iron dimers ${ }^{44}$ In the present system, as we see no similar feature, we conclude that the iron sites in these dilute, functional materials are not aggregated. The ZFS parameters used to fit the spectra of [Fe:ZnAl]-LDH are set out in Table 1, alongside those of model complexes with varying coordination geometries.

As in the iron case, two types of nickel sites were identifiable in 1\%-[Ni:ZnAl]LDH utilizing parallel-mode EPR. $\mathrm{B}_{D}(\mathrm{Ni})$ and $\mathrm{E}_{\mathrm{D}}(\mathrm{Ni})$ had significant differences in splittings, with very similar $g$-tensors, as expected for $\mathrm{B}(\mathrm{Ni})$ sites arising from bulk or inter-lattice $\mathrm{Ni}(\mathrm{II})$ in an octahedral ligand field (Figure 4). Furthermore, $\mathrm{E}(\mathrm{Ni})$ likely is an edge or defect $\mathrm{Ni}(\mathrm{II})$ site that changes coordination number and geometry under different hydration conditions. In the hydrated material, the spectrum was simulated using a single ensemble with the same ZF splitting parameters. $\mathrm{BD}_{\mathrm{D}}, \mathrm{BH}_{\mathrm{H}}$, and $\mathrm{E}_{\mathrm{H}}$ all 
exhibited ZF splittings similar to that of $\mathrm{Ni}(\mathrm{en})_{3}{ }^{2+}$ doped into $\mathrm{Zn}(\mathrm{en})_{3}\left(\mathrm{NO}_{3}\right)_{2}$ and $\mathrm{Ni}(\mathrm{II})$ doped into $\mathrm{ZnSiF}_{6} \bullet 6 \mathrm{H}_{2} \mathrm{O}$, both of which are 6-coordinate and octahedral. ${ }^{45,46}$

High-valent metal sites, such as $\mathrm{Ni}(\mathrm{III}), \mathrm{Fe}(\mathrm{IV}), \mathrm{Fe}(\mathrm{V})$ and $\mathrm{Fe}(\mathrm{VI})$ have been suggested in the water oxidation mechanisms in the related [NiFe]-LDH. ${ }^{9}$ The ability to monitor the oxidation state of the isolated $\mathrm{Fe}$ and $\mathrm{Ni}$ sites of [Fe:ZnAl]-LDH and [Ni:ZnAl]-LDH via EPR would be of great interest in this ongoing conversation. Attempts were made to oxidize both [Fe:ZnAl]-LDH and [Ni:ZnAl]-LDH with a number of chemical oxidants, both in aqueous and non-aqueous solvents. No spectral changes could unequivocally be attributed to oxidized Fe or Ni species. The spectroscopic features reported here provide a basis for further study of edge-site oxidation states.

Furthermore, although these materials feature $\mathrm{Fe}(\mathrm{III}) / \mathrm{Ni}(\mathrm{II})$ sites, the catalytic resting states of the functional catalysts are almost certainly $\mathrm{Fe}(\mathrm{III}) / \mathrm{Ni}(\mathrm{III})$. In this oxidized form, the iron centers would likely lose ligands before nickel, since $\mathrm{Ni}(\mathrm{III})$ would be substantially less labile than $\mathrm{Ni}(\mathrm{II})$. Thus, if ligand loss is an early step in catalysis, our analysis implicates iron. 


\begin{tabular}{|c|c|c|c|c|c|c|}
\hline Species & $\begin{array}{l}\text { Ligand } \\
\text { sphere }\end{array}$ & $\begin{array}{l}\text { Ligand } \\
\text { geometry }\end{array}$ & $\mathrm{D}\left(\mathrm{cm}^{-1}\right)$ & $\mathrm{E}\left(\mathrm{cm}^{-1}\right)$ & giso & citation \\
\hline \multicolumn{7}{|l|}{$\mathrm{Fe}(\mathrm{III})$} \\
\hline Class $\mathrm{B}_{\mathrm{H}}$ & $\mathrm{O}_{6}$ & $\mathrm{O}_{\mathrm{h}}$ & 0.20 & 0.044 & 2.003 & This work \\
\hline Class $B_{D}$ & $\mathrm{O}_{6}$ & $\mathrm{O}_{\mathrm{h}}$ & 0.19 & 0.050 & 2.003 & This work \\
\hline Class $\mathrm{E}_{\mathrm{H}}$ & $\mathrm{O}_{6}$ & $\mathrm{O}_{\mathrm{h}}$ & 0.21 & 0.020 & 2.003 & This work \\
\hline Class $\mathrm{E}_{\mathrm{D}}$ & $\mathrm{O}_{5}$ & Not $O_{\mathrm{h}}$ & -1.5 & 0.32 & 2.003 & This work \\
\hline $\mathrm{Fe}(\mathrm{III})$ in $\mathrm{PdTiO}_{3}$ & $\mathrm{O}_{6}$ & $\mathrm{O}_{\mathrm{h}}$ & 1.176 & 0 & 2.002 & 42 \\
\hline $\mathrm{Fe}(\mathrm{III})$ in $\mathrm{Al}_{2} \mathrm{O}_{3}$ & $\mathrm{O}_{6}$ & $\mathrm{O}_{\mathrm{h}}$ & 0.1683 & 0.00159 & 2.003 & 42 \\
\hline $\begin{array}{l}\mathrm{Fe}(\mathrm{III}) \text { citrate } \\
\mathrm{pH} 2\end{array}$ & $\mathrm{O}_{6}$ & $\mathrm{O}_{\mathrm{h}}$ & -0.12 & 0 & 2.004 & 47 \\
\hline $\begin{array}{l}\mathrm{Fe}(\mathrm{III}) \text { citrate } \\
\mathrm{pH} 6\end{array}$ & $\mathrm{O}_{6}$ & $\mathrm{O}_{\mathrm{h}}$ & 0.024 & 0.008 & 2 & 47 \\
\hline$\left[\mathrm{Fe}(\text { catecholate })_{3}\right]^{3-}$ & $\mathrm{O}_{6}$ & $\mathrm{O}_{\mathrm{h}}$ & 0.319 & 0.023 & 2 & 48 \\
\hline $\mathrm{Fe}(\mathrm{III})-\mathrm{EDTA}$ & $\mathrm{N}_{2} \mathrm{O}_{4}$ & $\mathrm{O}_{\mathrm{h}}$ & -0.77 & -0.21 & 2.004 & 49 \\
\hline $\begin{array}{l}\mathrm{Fe}(\mathrm{III}) \text {-transferrin } \\
\text { (Human) }\end{array}$ & $\mathrm{NO}_{5}$ & $\mathrm{O}_{\mathrm{h}}$ & 0.42 & 0.11 & & 50 \\
\hline Met-Hemoglobin & $\mathrm{N}_{4} \mathrm{O}$ & Sq. pyramidal & 10.7 & 0 & 1.95 & 51 \\
\hline $\begin{array}{l}\text { Met-Myoglobin } \\
\mathrm{Ni}(\mathrm{II})\end{array}$ & $\mathrm{N}_{4} \mathrm{O}$ & Sq. pyramidal & $9-9.5$ & 0 & 1.98 & 51 \\
\hline Class $\mathrm{B}_{\mathrm{H}}, \mathrm{E}_{\mathrm{H}}$ & $\mathrm{O}_{6}$ & & \pm 0.30 & 0.050 & 2.2 & This work \\
\hline Class $B_{D}$ & $\mathrm{O}_{6}$ & & \pm 0.30 & 0.050 & 2.2 & This work \\
\hline Class $E_{D}$ & $\mathrm{O}_{5}$ & & \pm 1.1 & 0.030 & 2.2 & This work \\
\hline$(\mathrm{Zn}, \mathrm{Ni}) \mathrm{SiF}_{6} \cdot 6 \mathrm{H}_{2} \mathrm{O}$ & $\mathrm{O}_{6}$ & & -0.6 & 0 & 2.26 & 46 \\
\hline $\mathrm{Ni}$ in $\mathrm{Zn}(\mathrm{en})_{3}$ & $\mathrm{O}_{6}$ & & 0.832 & 0 & 2.16 & 45 \\
\hline $\mathrm{Ni}($ Prtacn) & $\mathrm{N}_{3} \mathrm{Cl}_{2}$ & & 15 & 0.19 & 2.06 & 52 \\
\hline
\end{tabular}

Table 2. Comparison of ZF splitting parameters of isolated $\mathrm{Fe}(\mathrm{III})$ an $\mathrm{Ni}(\mathrm{II})$ centers in different coordination environments.

\section{Conclusions}

The identification and characterization of isolated $\mathrm{Fe}(\mathrm{III})$ and $\mathrm{Ni}(\mathrm{II})$ centers in

LDH-structured materials contribute to the ongoing discussion of their catalytic mechanisms. Ultimately, we aim to answer the question of which sites are active for electrocatalytic water splitting. Here, we find that iron and nickel at edge sites readily 
lose water and hydroxide ligands under gentle vacuum heating, revealing a possible mechanism by which high-valent metal-oxo units responsible for catalysis can be generated. However, the same speciation has been identified in both [Ni:ZnAl]-LDH and [Fe:ZnAl]-LDH, suggesting that iron and nickel sites can undergo similar geometric changes.

The structural changes seen at edge, corner, and defect sites are critically important for activity if the mechanism is hydroxide or water attack on a metal-oxo unit. To promote oxo attack by a nucleophile, there must be exceptionally strong metal-oxo $\pi$-bonding. ${ }^{53,54}$ Such bonding is not possible for lower-valent metals, as one or more of their $d$ electrons will be forced to occupy metal-oxo $\pi^{\star}$ orbitals. But with coordinatively unsaturated sites, multiple bonds to oxos can exist in lower oxidation states of iron.

\title{
Associated Content \\ Supporting Information \\ ICP-MS of synthesized materials, powder XRD of synthesized materials, calculation of zfs parameters, electrochemical characterization (CV/LSV), supporting figures and tables. This material is available free of charge via the Internet at http://pubs.acs.org.
}

\author{
Author Information \\ Corresponding Authors \\ rdbritt@ucdavis.edu
}




\section{Acknowledgments}

This work was supported by the NSF CCI Solar Fuels Program (CHE-1305124) and the Arnold and Mabel Beckman Foundation. 


\section{References}

(1) Gray, H. B. Powering the Planet with Solar Fuel. Nat. Chem. 2009, 1, 7.

(2) Anantharaj, S.; Karthick, K.; Kundu, S. Evolution of Layered Double Hydroxides (LDH) as High Performance Water Oxidation Electrocatalysts: A Review with Insights on Structure, Activity and Mechanism. Mater. Today Energy 2017, 6, 1-26.

(3) Hunter, B. M.; Gray, H. B.; Müller, A. M. Earth-Abundant Heterogeneous Water Oxidation Catalysts. Chem. Rev. 2016, 116, 14120-14136.

(4) Hunter, B. M.; Winkler, J. R.; Gray, H. B. Iron Is the Active Site in Nickel/Iron Water Oxidation Electrocatalysts. Molecules 2018, 23, 903.

(5) Trotochaud, L.; Young, S. L.; Ranney, J. K.; Boettcher, S. W. Nickel-Iron Oxyhydroxide Oxygen-Evolution Electrocatalysts: The Role of Intentional and Incidental Iron Incorporation. J. Am. Chem. Soc. 2014, 136, 6744-6753.

(6) Ullman, A. M.; Brodsky, C. N.; Li, N.; Zheng, S.-L.; Nocera, D. G. Probing Edge Site Reactivity of Oxidic Cobalt Water Oxidation Catalysts. J. Am. Chem. Soc. 2016, 138, 4229-4236.

(7) Friebel, D.; Louie, M. W.; Bajdich, M.; Sanwald, K. E.; Cai, Y.; Wise, A. M.; Cheng, M.J.; Sokaras, D.; Weng, T.-C.; Alonso-Mori, R.; Davis, R. C.; Bargar, J. R.; Nørskov, J. K.; Nilsson, A.; Bell, A. T. Identification of Highly Active Fe Sites in (Ni,Fe)OOH for Electrocatalytic Water Splitting. J. Am. Chem. Soc. 2015, 137, 1305-1313.

(8) Hunter, B. M.; Hieringer, W.; Winkler, J. R.; Gray, H. B.; Müller, A. M. Effect of Interlayer Anions on [NiFe]-LDH Nanosheet Water Oxidation Activity. Energy Environ. Sci. 2016, 9, 1734-1743.

(9) Hunter, B. M.; Thompson, N. B.; Müller, A. M.; Rossman, G. R.; Hill, M. G.; Winkler, J. R.; Gray, H. B. Trapping an Iron(VI) Water-Splitting Intermediate in Nonaqueous Media. Joule 2018, 2, 747-763.

(10) Li, N.; Bediako, D. K.; Hadt, R. G.; Hayes, D.; Kempa, T. J.; von Cube, F.; Bell, D. C.; Chen, L. X.; Nocera, D. G. Influence of Iron Doping on Tetravalent Nickel Content in Catalytic Oxygen Evolving Films. Proc. Natl. Acad. Sci. 2017, 114, 1486.

(11) Stevens, M. B.; Trang, C. D. M.; Enman, L. J.; Deng, J.; Boettcher, S. W. Reactive FeSites in Ni/Fe (Oxy)Hydroxide Are Responsible for Exceptional Oxygen Electrocatalysis Activity. J. Am. Chem. Soc. 2017, 139, 11361-11364.

(12) Song, F.; Hu, X. Exfoliation of Layered Double Hydroxides for Enhanced Oxygen Evolution Catalysis. Nat. Commun. 2014, 5, 4477.

(13) Hunter, B. M.; Blakemore, J. D.; Deimund, M.; Gray, H. B.; Winkler, J. R.; Müller, A. M. Highly Active Mixed-Metal Nanosheet Water Oxidation Catalysts Made by Pulsed-Laser Ablation in Liquids. J. Am. Chem. Soc. 2014, 136, 13118-13121.

(14) Dincă, M.; Surendranath, Y.; Nocera, D. G. Nickel-Borate Oxygen-Evolving Catalyst That Functions under Benign Conditions. Proc. Natl. Acad. Sci. 2010, 107, 10337.

(15) Bediako, D. K.; Lassalle-Kaiser, B.; Surendranath, Y.; Yano, J.; Yachandra, V. K.; Nocera, D. G. Structure-Activity Correlations in a Nickel-Borate Oxygen Evolution Catalyst. J. Am. Chem. Soc. 2012, 134, 6801-6809. 
(16) Ruby, C.; Usman, M.; Naille, S.; Hanna, K.; Carteret, C.; Mullet, M.; François, M.; Abdelmoula, M. Synthesis and Transformation of Iron-Based Layered Double Hydroxides. Synth. Clay-Based Mater. Layer. Double Hydroxides 2010, 48, 195-202.

(17) Cox, N.; Pantazis, D. A.; Neese, F.; Lubitz, W. Biological Water Oxidation. Acc. Chem. Res. 2013, 46, 1588-1596.

(18) Cox, N.; Retegan, M.; Neese, F.; Pantazis, D. A.; Boussac, A.; Lubitz, W. Electronic Structure of the Oxygen-Evolving Complex in Photosystem II Prior to O-O Bond Formation. Science 2014, 345, 804.

(19) Oyala, P. H.; Stich, T. A.; Debus, R. J.; Britt, R. D. Ammonia Binds to the Dangler Manganese of the Photosystem II Oxygen-Evolving Complex. J. Am. Chem. Soc. 2015, 137, 8829-8837.

(20) Kanan, M. W.; Nocera, D. G. In Situ Formation of an Oxygen-Evolving Catalyst in Neutral Water Containing Phosphate and $\mathrm{Co}^{2+}$. Science 2008, 321 (5892), 1072.

(21) Marchiori, D. A.; Oyala, P. H.; Debus, R. J.; Stich, T. A.; Britt, R. D. Structural Effects of Ammonia Binding to the $\mathrm{Mn}_{4} \mathrm{CaO}_{5}$ Cluster of Photosystem II. J. Phys. Chem. B 2018, 122, 1588-1599.

(22) Howe, R. F.; Gratzel, Michael. EPR Study of Hydrated Anatase under UV Irradiation. $J$. Phys. Chem. 1987, 91, 3906-3909.

(23) McAlpin, J. G.; Surendranath, Y.; Dincă, M.; Stich, T. A.; Stoian, S. A.; Casey, W. H.; Nocera, D. G.; Britt, R. D. EPR Evidence for Co(IV) Species Produced During Water Oxidation at Neutral PH. J. Am. Chem. Soc. 2010, 132, 6882-6883.

(24) Goldfarb, D.; Strohmaier, K. G.; Vaughan, D. E. W.; Thomann, H.; Poluektov, O. G.; Schmidt, J. Studies of Framework Iron in Zeolites by Pulsed ENDOR at 95 GHz. J. Am. Chem. Soc. 1996, 118, 4665-4671.

(25) Baute, D.; Arieli, D.; Neese, F.; Zimmermann, H.; Weckhuysen, B. M.; Goldfarb, D. Carboxylate Binding in Copper Histidine Complexes in Solution and in Zeolite Y: X- and W-Band Pulsed EPR/ENDOR Combined with DFT Calculations. J. Am. Chem. Soc. 2004, 126, 11733-11745.

(26) Pietrzyk, P.; Podolska, K.; Mazur, T.; Sojka, Z. Heterogeneous Binding of Dioxygen: EPR and DFT Evidence for Side-On Nickel(II)-Superoxo Adduct with Unprecedented Magnetic Structure Hosted in MFI Zeolite. J. Am. Chem. Soc. 2011, 133, 19931-19943.

(27) Brozek, C. K.; Dincă, M. Ti ${ }^{3+}-, \mathrm{V}^{2+/ 3+}-, \mathrm{Cr}^{2+/ 3+}-, \mathrm{Mn}^{2+}-$, and $\mathrm{Fe}^{2+}-\mathrm{Substituted} \mathrm{MOF-5}$ and Redox Reactivity in Cr- and Fe-MOF-5. J. Am. Chem. Soc. 2013, 135, 12886-12891.

(28) Peloquin, J. M.; Campbell, K. A.; Randall, D. W.; Evanchik, M. A.; Pecoraro, V. L.; Armstrong, W. H.; Britt, R. D. 55Mn ENDOR of the S2-State Multiline EPR Signal of Photosystem II: Implications on the Structure of the Tetranuclear Mn Cluster. J. Am. Chem. Soc. 2000, 122, 10926-10942.

(29) Kim, D. H.; Britt, R. D.; Klein, M. P.; Sauer, K. The Manganese Site of the Photosynthetic Oxygen-Evolving Complex Probed by EPR Spectroscopy of Oriented Photosystem II Membranes: The $\mathrm{g}=4$ and $\mathrm{g}=2$ Multiline Signals. Biochemistry 1992, 31, 541-547.

(30) Jung, S.; McCrory, C. C. L.; Ferrer, I. M.; Peters, J. C.; Jaramillo, T. F. Benchmarking Nanoparticulate Metal Oxide Electrocatalysts for the Alkaline Water Oxidation Reaction. J. Mater. Chem. A 2016, 4, 3068-3076.

(31) Oloo, W. N.; Que, L. Bioinspired Nonheme Iron Catalysts for $\mathrm{C}-\mathrm{H}$ and $\mathrm{C}=\mathrm{C}$ Bond Oxidation: Insights into the Nature of the Metal-Based Oxidants. Acc. Chem. Res. 2015, $48,2612-2621$. 
(32) Codolà, Z.; Gómez, L.; Kleespies, S. T.; Que Jr, L.; Costas, M.; Lloret-Fillol, J. Evidence for an Oxygen Evolving Iron-Oxo-Cerium Intermediate in Iron-Catalysed Water Oxidation. Nat. Commun. 2015, 6, 5865.

(33) Gersten, S. W.; Samuels, G. J.; Meyer, T. J. Catalytic Oxidation of Water by an OxoBridged Ruthenium Dimer. J. Am. Chem. Soc. 1982, 104, 4029-4030.

(34) Nguyen, A. I.; Suess, D. L. M.; Darago, L. E.; Oyala, P. H.; Levine, D. S.; Ziegler, M. S.; Britt, R. D.; Tilley, T. D. Manganese-Cobalt Oxido Cubanes Relevant to ManganeseDoped Water Oxidation Catalysts. J. Am. Chem. Soc. 2017, 139, 5579-5587.

(35) Stoll, S.; Schweiger, A. EasySpin, a Comprehensive Software Package for Spectral Simulation and Analysis in EPR. J. Magn. Reson. 2006, 178, 42-55.

(36) Oyala, P. H.; Ravichandran, K. R.; Funk, M. A.; Stucky, P. A.; Stich, T. A.; Drennan, C. L.; Britt, R. D.; Stubbe, J. Biophysical Characterization of Fluorotyrosine Probes SiteSpecifically Incorporated into Enzymes: E. Coli Ribonucleotide Reductase As an Example. J. Am. Chem. Soc. 2016, 138, 7951-7964.

(37) Krzystek, J.; Park, J.-H.; Meisel, M. W.; Hitchman, M. A.; Stratemeier, H.; Brunel, L.-C.; Telser, J. EPR Spectra from "EPR-Silent" Species: High-Frequency and High-Field EPR Spectroscopy of Pseudotetrahedral Complexes of Nickel(II). Inorg. Chem. 2002, 41, 4478-4487.

(38) Aasa, R.; Vänngård, tore. EPR Signal Intensity and Powder Shapes: A Reexamination. J. Magn. Reson. 1969 1975, 19, 308-315.

(39) Campbell, K. A.; Lashley, M. R.; Wyatt, J. K.; Nantz, M. H.; Britt, R. D. Dual-Mode EPR Study of Mn(III) Salen and the Mn(III) Salen-Catalyzed Epoxidation of Cis- $\beta$ Methylstyrene. J. Am. Chem. Soc. 2001, 123, 5710-5719.

(40) Williams, R. J. P. Biological Magnetic Resonance, Vol. 1, Plenum Press, New York and London, 1978.

(41) Wright, C. M. R.; Ruengkajorn, K.; Kilpatrick, A. F. R.; Buffet, J.-C.; O’Hare, D. Controlling the Surface Hydroxyl Concentration by Thermal Treatment of Layered Double Hydroxides. Inorg. Chem. 2017, 56, 7842-7850.

(42) Krzystek, J.; Ozarowski, A.; Telser, J. Multi-Frequency, High-Field EPR as a Powerful Tool to Accurately Determine Zero-Field Splitting in High-Spin Transition Metal Coordination Complexes. 20th Int. Conf. Coord. Bioinorg. Chem. 2006, 250, 2308-2324.

(43) Goldfarb, D.; Bernardo, M.; G. Strohmaier, K.; Vaughan, D.; Thomann, H. Characterization of Iron in Zeolites by X-Band and Q-Band ESR, Pulsed ESR, and UVVisible Spectroscopies. J. Am. Chem. Soc. 1994,116, 6344-6353.

(44) Osadchii, D. Y.; Olivos-Suarez, A. I.; Szécsényi, Á.; Li, G.; Nasalevich, M. A.; Dugulan, I. A.; Crespo, P. S.; Hensen, E. J. M.; Veber, S. L.; Fedin, M. V.; Sankar, G.; Pidko, E. A.; Gascon, J. Isolated Fe Sites in Metal Organic Frameworks Catalyze the Direct Conversion of Methane to Methanol. ACS Catal. 2018, 8, 5542-5548.

(45) Sreeramachandra Prasad, L.; Subramanian, S. Zero Field Tensor for Ni(II) in Zn (Ethylenediamine $)_{3}\left(\mathrm{NO}_{3}\right)_{2}$ : EPR Study. J. Chem. Phys. 1988, 88, 43-45.

(46) Shrivastava, K. N.; Rubins, R. S.; Hutton, S.; Drumheller, J. E. Temperature Dependence of the $\mathrm{g}$ Value of $\mathrm{Ni}^{2+}$ in $\mathrm{ZnSiF6} \cdot 6 \mathrm{H} 2 \mathrm{O}$. J. Chem. Phys. 1988, 88, 705-706.

(47) Biaso, F.; Duboc, C.; Barbara, B.; Serratrice, G.; Thomas, F.; Charapoff, D.; Béguin, C. High-Field EPR Study of Frozen Aqueous Solutions of Iron(III) Citrate Complexes. Eur. J. Inorg. Chem. 2005, 2005, 467-478. 
(48) Weisser, J. T.; Nilges, M. J.; Sever, M. J.; Wilker, J. J. EPR Investigation and Spectral Simulations of Iron-Catecholate Complexes and Iron-Peptide Models of Marine Adhesive Cross-Links. Inorg. Chem. 2006, 45, 7736-7747.

(49) Mathies, G.; Blok, H.; Disselhorst, J. A. J. M.; Gast, P.; van der Meer, H.; Miedema, D. M.; Almeida, R. M.; Moura, J. J. G.; Hagen, W. R.; Groenen, E. J. J. Continuous-Wave EPR at 275GHz: Application to High-Spin $\mathrm{Fe}^{3+}$ Systems. J. Magn. Reson. 2011, 210, 126-132.

(50) Mathies, G.; Gast, P.; Chasteen, N. D.; Luck, A. N.; Mason, A. B.; Groenen, E. J. J. Exploring the Fe(III) Binding Sites of Human Serum Transferrin with EPR at $275 \mathrm{GHz}$. JBIC J. Biol. Inorg. Chem. 2015, 20, 487-496.

(51) Nehrkorn, J.; Martins, B. M.; Holldack, K.; Stoll, S.; Dobbek, H.; Bittl, R.; Schnegg, A. Zero-Field Splittings in MetHb and MetMb with Aquo and Fluoro Ligands: A FD-FT THz-EPR Study. Mol. Phys. 2013, 111, 2696-2707.

(52) Rebilly, J.-N.; Charron, G.; Rivière, E.; Guillot, R.; Barra, A.-L.; Serrano, M. D.; van Slageren, J.; Mallah, T. Large Magnetic Anisotropy in Pentacoordinate $\mathrm{Ni}^{\mathrm{II}}$ Complexes. Chem. Eur. J. 2008, 14, 1169-1177.

(53) Winkler, J. R.; Gray, H. B. Electronic Structures of Oxo-Metal Ions. In Molecular Electronic Structures of Transition Metal Complexes I; Mingos, D. M. P., Day, P., Dahl, J. P., Eds.; Springer Berlin Heidelberg: Berlin, Heidelberg, 2012; pp 17-28.

(54) Gray, H. B.; Winkler, J. R. Living with Oxygen. Acc. Chem. Res. 2018, 51, 1850-1857. 


\section{Table of Contents Graphic}

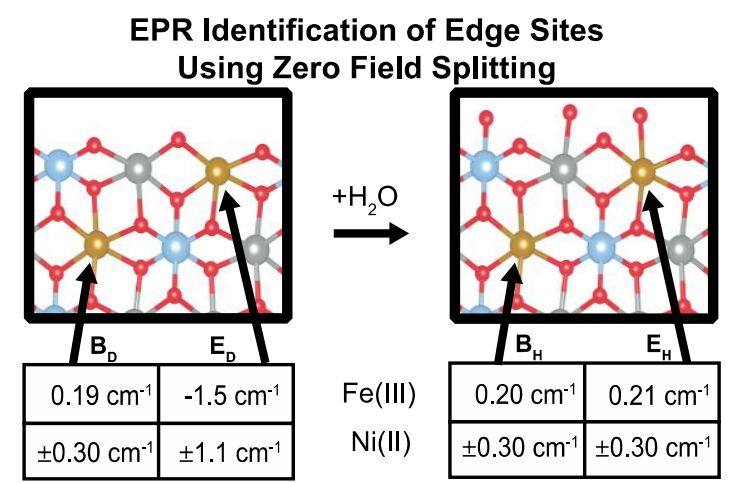

